\title{
小泊，福井県の流れ藻から取れたワレカラ類
}

挿図 4

有 元 石 太 郎

（東京水産大学, 資料館）

\section{ON CAPRELLIDS WITH DRAFING SEA WOODS \\ FROM KODOMARI, FUKUI PREF., JAPAN}

With 4 Text-figures

By

\section{Ishitaro ARIMOTO}

(Museum of Fishery Science, Tokyo University of Fisheries)

\begin{abstract}
A check of the flow at Kodomari indicates the existence of the following four species of caprellids. Of them, the gregariousness of Caprella $(R$.) penantis is most conspicuous. This phenonmenon has something to do with the fact that this species inhabits shallows.
\end{abstract}

ホンダワラ類を主体とする海藻類等が，海表面あるいは海表面近くを漂い流れる場合は，こ れを流れ藻という。

広崎 (1962) によると, 江, 島近海に出現する流れ藻を構成する種類は, 緑藻類 4 種, 褐藻 類18種, 紅藻類 1 種および単子葉植物 1 種で, 真生ホンダワラ（Eusargassum 類）のごとく 江ノ島近海の藻場では生育の認められていない種類も含まれていた。そして緑藻類ならびに紅 藻類は単独で流れ藻として存在していることは，泀とんどなく，多くはホンダワラ類に少量が 混在し浮漂しているに過ぎない。ホンダワラ類は，水面または水中に垂下して塊りをつくりな がら漂っている。月別の出現種類数は，1956年から1958年の 3 カ年を通じ, 流れ藻の種類の最 も多い月は，6月から 8 月，これに次いで12月である。またその流れ藻の量は，春から初夏の ころ最も多いようである。これは, その頃に, 繁茂する種類に, 個体として大きくなるものが あることと，風波などが原因と思われるという。

そうして, 広崎は1956年から1958年にわたる流れ藻を調査して, その出現箇数の最も多かっ たのは，1956年 8 月 6 日で，128個体を数えている。そして，3 カ年間の平均值は，1 日当り 30 箇という。

今までの流れ藻の研究では, 流れ藻には若干の魚類がついており, その多くは雅仔魚である ところから, 流れ藻にこれらの魚類の生活史に拈いて重要なる関連をもつものが主であって, ワレカラを主体とした研究はまだない。 


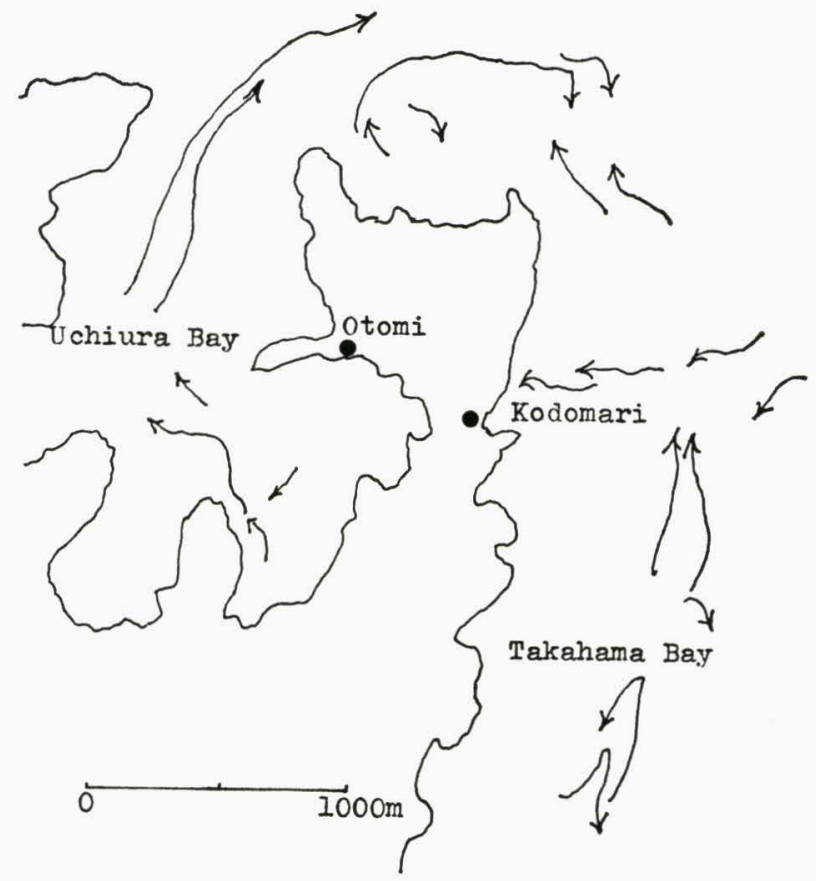

Text-fig. 1. Current of the sea of $2 \mathrm{~m}$ under sea (from T. YASUDA, 1971).

筆者は1969年 7 月29日に, 安田 徹（福井県水産試験場）と, 福井県の小泊において, ホン ダワラの流れ藻 $720 \mathrm{~g}$ (湿重量) を採集して, それに付着するワレカラを調べた。ここに安田 徹博士に対し, 深甚の謝意を表する。

\section{小泊の流れ藻に付着していたワレカラ}

小泊の流れ藻は, その供給源は恐らく, 豊かに茂った藻場が近くにあるから, そこから流れ てきたものと思われるが, 海流の関連で他から流れてきたものかも知れない。この流れ藻は, 手ですくいあげられたものであるから，そこにいただろと思われる小魚あるいは，ガマルスの 一部などは，すくいあげるときに逃げたものもあろらけれども，この流れ藻には，そのほとん どが, ワレカラのみであった。広崎によると, 慎重なる採集の結果も, そのほとんどが, 甲殼 類が主体をしめている。

そのワレカラを調べたところ，次の通りであった。

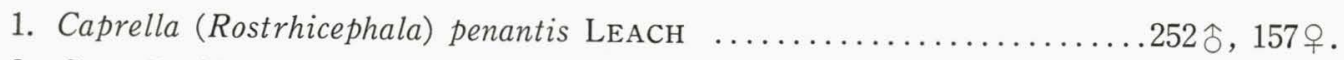

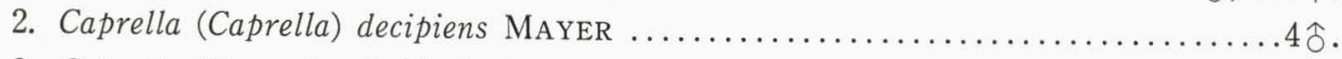

3. Caprella (Rostrhicephala) danilevskii CzERnIAveski .....................

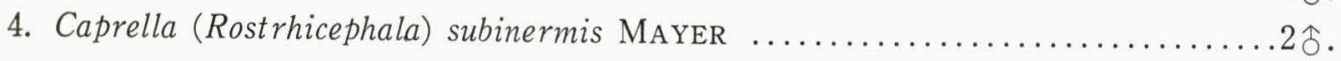

本調査では, 材料を一匹づつその体長を測定し, それを体長の短いものから長いものの順に ならべ, Penantis について第 3 図及び第 4 図を得た。このワレカラが, この流れ藻においての 主体をして扣り, 雄と雌が適当に混りあっているから,この社会内で仔を産むことができる。 


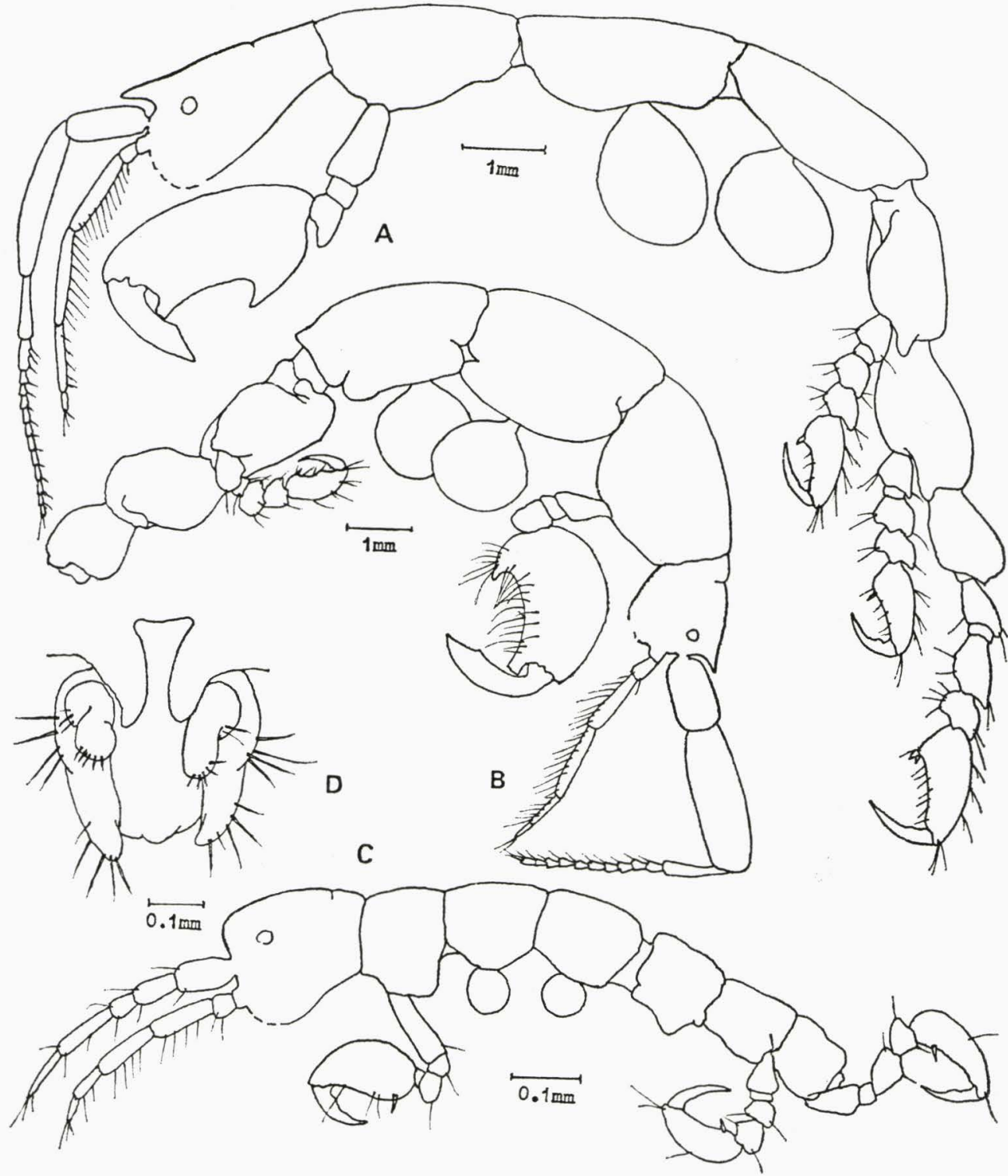

Text-fig. 2. Caprella (Rostrhicephala) penantis LEACH. A, adult male; B, adult male; C, larva; D, abdomen of male.

雄は睬化してから間もないと思われる体長 $1.1 \mathrm{~mm}$ のものから $8 \mathrm{~mm}$ の成虫まで, 雌は体長 $3 \mathrm{~mm}$ から $6 \mathrm{~mm}$ までいた。この大きさは, 成長の途中のものであって, 雄の最大と思われる ものは, $20 \mathrm{~mm}$ (有元：淡路島, IV 11, 1920) で, 雌は $10.5 \mathrm{~mm}$ (有元：川奈沖, VI 20, 1969) である。 

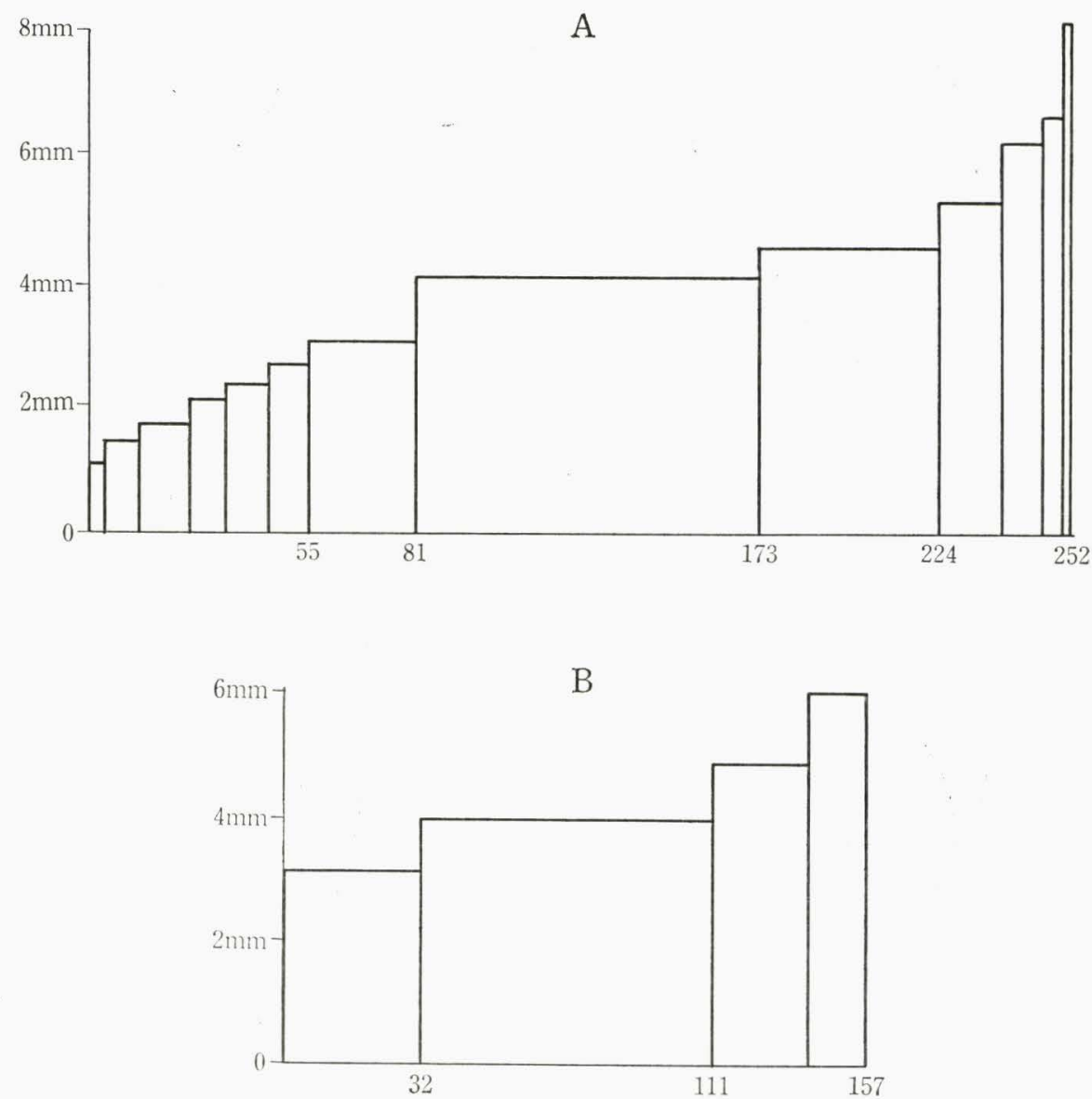

Text-fig. 3. A: Body length and individual number in male; $1.1 \mathrm{~mm} 4 ; 1.4 \mathrm{~mm} 7$; $1.6 \mathrm{~mm} 13 ; 2.0 \mathrm{~mm} 9 ; 2.6 \mathrm{~mm} 12 ; 3.0 \mathrm{~mm} 10 ; 3.4 \mathrm{~mm} 26 ; 4.0 \mathrm{~mm} 92 ; 4.4 \mathrm{~mm}$ $51 ; 5.2 \mathrm{~mm} 17 ; 6.0 \mathrm{~mm} 6 ; 6.5 \mathrm{~mm} 4 ; 8.0 \mathrm{~mm} 1$.

B: Body length and individual number in female; $3.0 \mathrm{~mm} 32 ; 4.0 \mathrm{~mm}$ $79 ; 4.5 \mathrm{~mm} 29 ; 6.0 \mathrm{~mm} 17$.

雄も雌も, この流れ藻の場合は, その体長 $4 \mathrm{~mm}$ のものが, 最も多く, 成長するにしたがっ て, その数が漸減している。これは恐らく，このワレカラが魚などに食われる率が大きいもの ほど多いことによると思われる。ところが $4 \mathrm{~mm}$ 以下のものも, また少い。これは恐らく, こ の集団内で生まれたものであろう。

penantis は, 内湾性の性質を獲得したワレカラである。内溜は河水の流入があるため塩分濃 度は薄く, 種々の有機物が流入するから養分も多くなる。それに加党て風波は外洋に比べて静 かである。もともと, ワレカラは, 北方の深海と南方の深海とで, 発生して, たがいにとの分 布を拡げて，ほとんど地球の全体に分布していると思われる。ところが，あるかぎられた種類 が内湾に進出した。内湾には, 海藻が豊富であり, 海藻のある所には, 食慨となる小動物やプ ランクトンも多い。それに海藻は好適のかくれ場所を与えてくれる。だが，この場所に生活で 


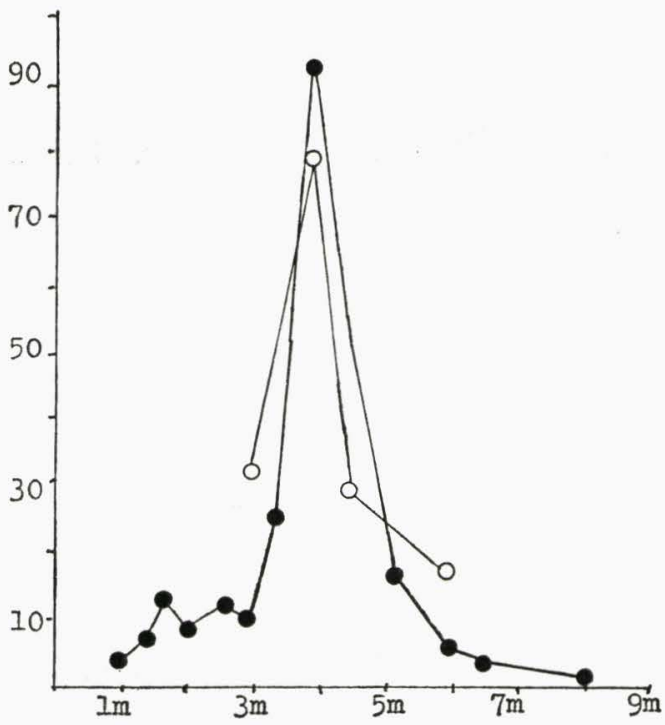

Text-fig. 4. Individual of caprellids. male, $\bigcirc$ female.

きるのには, 先づ, 体が塩分濃度の減少に耐えられなければならない。次に体形の変化がなけ ればならない。後方の 3 対の脚は, 海藻を摑むのに便利で丈夫でなくてはいけない。第 3 , 第 4 脚は下用になる。それから体形が余り長いとまずい。こういうような難点を克服してから， 内湾性のものが, 後からできた。内湾に生活するものは, その食飼の豊富からか無数に殖え, ついに一つの群を成して生活するようになった。

かかる流孔藻の penantis が対島海流に乗って北上し, 日本海の北方地方, ことに礼文島あ たりまで達している。このように，世界中のあちらこちらの内湾に分布を拡げ，元来のワレカ ラの分布を一見複雑なものにさせた。その最大の原因は, 流れ藻に乗って分布をするものと考 えられる。

\section{引用文 献}

広崎芳次, 1963. 流れ藻につく魚類の生態学的研究 I. 方法及び環境。資源科学研究所彙報, 60 号：6674.

一，1963. 流れ藻につく魚類の生態学的研究II. 流れ藻及び魚類, 資源科学研究所采報, 61号：7784.

，1964. 流れ藻につく魚類の生態学的研究正. 魚類以外の 動物相, 資源科学 研究所彙報, 62 号： 63-70.

安田 徹, 1974. 福井県若狭海域における原子力発電所温排水環境と漁業生産に及ぼす影響に関する調査報 告; 16-19. 